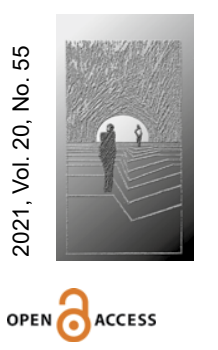

\title{
Zjawisko niewidoczności w czasach zdalnego nauczania jako bezprecedensowy sprawdzian współodpowiedzialności w edukacji
}

\section{STRESZCZENIE}

CEL NAUKOWY: Celem rozważań jest zaprezentowanie i możliwie wieloaspektowe omówienie zjawiska uczniowskiej „niewidoczności” w czasach, gdy nauka systemowa po raz pierwszy została realizowana $\mathrm{w}$ formie distance teaching.

PROBLEM I METODY BADAWCZE: Głównym problemem publikacji jest ujęcie i w konsekwencji zaprezentowanie wieloaspektowości zjawiska uczniowskiej „niewidoczności” w czasach zdalnego nauczania. Czynnikiem inicjującym prezentowane rozważania było doświadczenie autorki zanurzonej w konkretnym wycinku rzeczywistości edukacyjnej. Zastosowana została strategia poszukiwawcza (bazująca na analizie) wobec omawianego zagadnienia, pytań o jego istotę, specyfikę i strukturę oraz wobec odczytywania sensu i znaczenia obserwowanych zjawisk.

PROCES WYWODU: We wprowadzeniu opisany został sposób komunikowania się podczas działań e-learningowych, dzięki czemu możliwe stało się ukazanie zagadnienia komunikacyjnej nieprzejrzystości i wiążącej się z nią uczniowskiej niewidoczności. W kolejnych częściach niewidoczność ukazana została jako potrzeba, niebezpieczeństwo oraz bezprecedensowy test współczesnej edukacji, która nierzadko wypiera istnienie świadomie współodpowiedzialnego podejścia do uczenia się i nauczania.

WYNIKI ANALIZY NAUKOWEJ: Finalna analiza omawianego zjawiska dość nieoczekiwanie przekierowuje odbiorcę ze zjawiska niewidoczności na problem braku uczniowskiej i nauczycielskiej współodpowiedzialności. Ten specyficzny deficyt odczuwania i poczuwania się do współodpowiedzialności przedstawiony zostaje jako główna przyczyna „niskiej noty” za zdalne nauczanie.

WNIOSKI, INNOWACJE, REKOMENDACJE: Niniejsza publikacja wskazuje na konieczność pielęgnowania poczucia dydaktyczno-wychowawczej współodpowiedzialności, której występowanie w czasach zdalnego nauczania mogłoby stać się równoważne z rozwiązaniem problemu niepożądanego zjawiska niewidoczności w czasach zdalnego nauczania.

$\rightarrow$ SŁOWA KLUCZOWE: NIEWIDOCZNOŚĆ, ZDALNE NAUCZANIE, WSPÓŁODPOWIEDZIALNOŚĆ, ZABURZONA WIDOCZNOŚĆ/ KOMUNIKACJA 


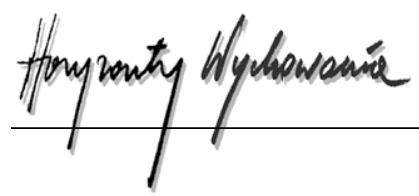

ABSTRACT

The Phenomenon of Invisibility in the Era of Distance Teaching as an Unprecedented Test of Co-responsibility in Education

RESEARCH OBJECTIVE: The aim of this paper is to present and discuss multifaceted issues of the phenomenon of pupil "invisibility" at the time when system teaching was first implemented in the form of distance teaching.

THE RESEARCH PROBLEM AND METHODS: The main problem of the publication is to capture and consequently present the multifaceted nature of the phenomenon of student "invisibility" in the era of distance teaching. The factor initiating the presented considerations was the author's experience immersed in a specific fragment of the educational reality. An exploratory strategy (based on analysis) was applied to the discussed issue questions about its essence, specificity and structure, and to reading the sense and meaning of the observed phenomena.

THE PROCESS OF ARGUMENTATION: In the introduction, the mode of communication during e-learning activities was described, thanks to which it became possible to show the issue of communicative opacity and the related student invisibility. In the following sections, invisibility is shown as a need, danger, and an unprecedented test of contemporary education, which often supersedes the existence of a consciously co-responsible approach to learning and teaching.

RESEARCH RESULTS: The final analysis of the discussed phenomenon quite unexpectedly redirects the recipient from the phenomenon of invisibility to the problem of lack of student and teacher co-responsibility. This specific deficit of feeling co-responsibility is presented as a main reason for the "low score" for distance teaching.

CONCLUSIONS, INNOVATIONS, AND RECOMMENDATIONS: This publication points to the need to cultivate a sense of didactic and upbringing co-responsibility, the occurrence of which in the era of distance teaching could become equal to solving the undesirable phenomenon of invisibility in the era of distance teaching.

$\rightarrow$ KEYWORDS: INVISIBILITY, DISTANCE TEACHING, CO-RESPONSIBILITY, IMPAIRED VISIBILITY/COMMUNICATION

\section{Wprowadzenie}

Przeniesienie działań dydaktyczno-wychowawczych w obszar zdalnego nauczania było nieoczekiwanym zjawiskiem, które rozpoczęło się w Polsce w związku z epidemią COVID-19 w marcu 2020 roku (z przerwą na chwilowy powrót do szkół w trybie kontaktowym). Ze względu na zróżnicowany poziom kompetencji cyfrowych nauczycieli, uczniów i ich opiekunów, niezadowalające i nierzadko ograniczające technologiczne zaplecze placówek edukacyjnych oraz domowych gospodarstw, a także inne kwestie obejmujące 
specyfikę prowadzenia zajęć on-line, to nagłe przeniesienie stało się ogromnym wyzwaniem zarówno dla zagubionych i zdezorientowanych uczniów, ich rodziców, jak i nauczycieli. Wyzwanie obejmowało między innymi konieczność szybkiego i dostatecznie efektywnego przygotowania się do edukacji na odległość w obszarze stricte technicznym oraz kompetencyjnym (a także metodycznym - w przypadku prowadzących zajęcia), co przełożyło się na to, że wielu nauczycieli i rodziców musiało zakupić nowy sprzęt, dokupić transfer internetowy czy też zainstalować dodatkowe oprogramowanie i jednocześnie nauczyć siebie i swoich podopiecznych korzystania z różnorodnych narzędzi komunikacyjnych, rozbudowanego wachlarza aplikacji, narzędzi, programów i niezbędnego sprzętu (Ptaszek i in., 2020, s. 26). Działania te skoncentrowane były zatem na ograniczaniu sposobności do pojawienia się sytuacji cyfrowego wykluczenia, które utożsamiane jest z formą wykluczenia społecznego (Kujawski, 2018). Organizacyjną złożoność i obszar zarysowujących się trudności w związku z wprowadzeniem edukacji na odległość podkreślają doniesienia opublikowane w raporcie Centrum Cyfrowego, w którym odnaleźć można informację, że tylko 15\% nauczycieli z prawie 1000 biorących udział w badaniu zadeklarowało kontakt $z$ edukacją zdalną przed epidemią koronawirusa (Centrum Cyfrowe, 2020). Z tą niekomfortową sytuacją uwarunkowaną wymaganiami i ograniczeniami zdalnego nauczania zmagali się wszyscy, także kraje zamożne i technologicznie rozwinięte (Pauluk, 2021, s. 41).

Przed pojawieniem się COVID-19 edukacja zdalna w Polsce stanowiła element wspierający, urozmaicający czy też wzbogacający lekcje prowadzone w szkole powszechnej, natomiast w 2020 roku po raz pierwszy edukacja na odległość (distance learning) stała się nieoczekiwanie edukacją systemową. W związku z tym wszelkie działania podejmowane do tej pory na zajęciach odbywających się w klasie szkolnej musiały zostać całkowicie przetransformowane i przeniesione w świat zamknięty za ekranem monitora, czyli w obszar, którego przestrzeń wyznaczają linie prowadzące od myszki i klawiatury do ekranu i z powrotem. Nauczanie oparte na założeniach d-learningu wydaje się zarówno ogromnym wyzwaniem (o czym już wspominałam), jak i niepowtarzalną możliwością. Z nauczaniem na odległość bowiem wiąże się między innymi wprowadzenie i wykorzystywanie nowych technologii i rozwiązań czy też pożądana możliwość autonomicznego, elastycznego zarządzania przez uczniów procesem uczenia się, na co wskazują respondenci badań przeprowadzonych przez Reimersa i Schleichera (2020), odpowiadając na pytanie: Have there been unexpected positive educational results from the changes?

Odczytaniu obecnej sytuacji edukacyjnej zarówno jako wyzwania, jak i możliwości towarzyszy specyficzne niebezpieczeństwo wyartykułowane już w tytule niniejszych rozważań, mianowicie problem uczniowskiej niewidoczności. Stanowi ono centralny punkt prezentowanych przemyśleń i w dalszych częściach artykułu przedstawione i zinterpretowane zostanie jako sposobność do ukrywania się, niebezpieczeństwo oraz bezprecedensowy test współczesnej edukacji w kontekście współodpowiedzialności za każde podejmowane na gruncie edukacyjnym przedsięwzięcie. Wobec omawianego zagadnienia, pytań o jego istotę, specyfikę i strukturę oraz odczytywania sensu i znaczenia obserwowanych zjawisk zastosowałam strategię poszukiwawczą bazującą na analizie 


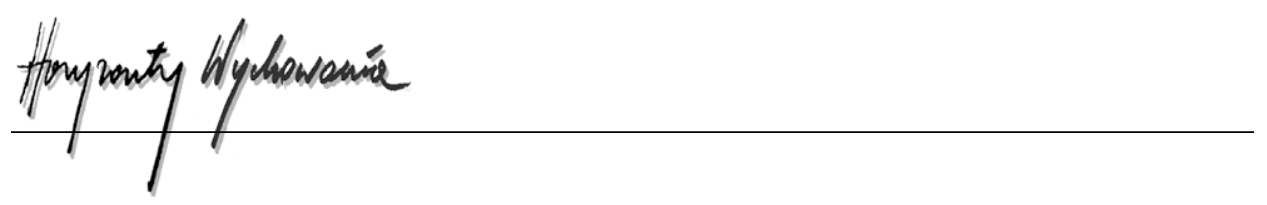

wybranej literatury, co doprowadziło do wniosków podkreślających istotę współodpowiedzialności w edukacji.

\section{Od komunikacyjnej nieprzejrzystości do uczniowskiej niewidoczności}

Rozpocznę od próby opisania i sformułowania cech komunikacji w zdalnym nauczaniu, co uznać można za wprowadzenie w zagadnienie „uczniowskiej niewidoczności”. W nauczaniu e-learningowym i wszelkich czynnościach z nim związanych doszukać się można wielu zalet, jak i wad. Wśród tej drugiej grupy niesamowicie rażąca wydaje się pośredniość i nieprzejrzystość komunikacyjna, rozumiana jako nieczytelność odbieranych komunikatów lub/i niemożność ich rzetelnej interpretacji. Sama komunikacja definiowana jest jako „proces porozumiewania się jednostek, grup lub instytucji, których celem jest wymiana myśli i dzielenie się wiedzą, informacjami oraz ideami” (Dobek-Ostrowska, 2002, s. 13). W podejściu tradycyjnym, w ujęciu George'a Millera, komunikowanie sprowadza się do czynności transmitowania informacji z jednego miejsca do innego (Nęcki, 2000, s. 20-21), a w omawianym procesie wyodrębnia się pięć klas uwzględnionych na poniższej grafice, na której ukazano specyfikę komunikacji za pośrednictwem Internetu w perspektywie zdalnego nauczania.

Rysunek 1. Specyfika komunikacji w edukacji zdalnej.

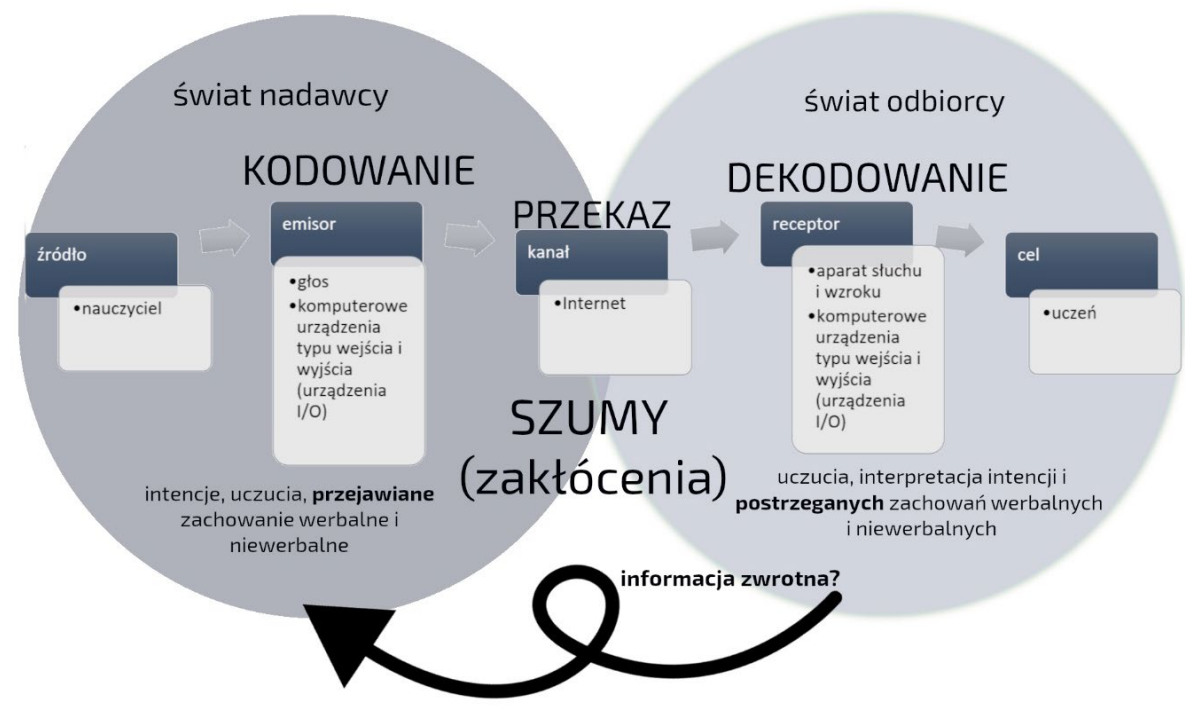

Źródło: opracowanie własne. 
Analizując rysunek 1, skonstruować można kilka wniosków dotyczących cech charakterystycznych komunikacji na płaszczyźnie nauczyciel - uczeń podczas działań e-learningowych:

1. Nauczyciel jest specyficznym nadawcą komunikatu, nadającym tenże komunikat poprzez emisory biologiczne i urządzenia wspierające (np. poprzez komputerowe urządzenia I/O, czyli kamerkę, klawiaturę itp.).

2. Nauczyciel mający włączoną kamerę przejawia zachowania niewerbalne, które są dostępne dla uczniów.

3. Uczniowie jako odbiorcy komunikatu interpretują intencję, komunikat słowny oraz ewentualne postrzegane zachowania niewerbalne nauczyciela, uzyskując (prawie) pełny komunikat.

4. Informacja zwrotna może nastąpić, ale zależy to między innymi od nastawienia, aktywności i zaangażowania ucznia-odbiorcy. Forma feedbacku (włączony mikrofon, włączona kamerka) wpływa na jakość, czytelność i kompletność przekazywanych informacji zwrotnych.

W związku z ostatnim podpunktem i możliwością niewłączenia kamerki przez ucznia nauczyciel może otrzymać informację zwrotną niepełną lub nieprzejrzystą, próbując odczytać komunikat zakodowany werbalnie: pisemnie lub ustnie (bez prezentacji wizualnej). Co więcej, w momencie gdy uczeń zdecyduje się przekazać informację tylko pisemnie, nauczyciel pozbawiony zostaje możliwości interpretacji wielu znaków i kodów niewerbalnych, takich jak na przykład mimika twarzy (mikroekspresje), specyficzna gestykulacja (kinezjetyka), ton, barwa, wysokość, natężenie głosu, a także wtrącenia, zakłócenia płynności mowy (parajęzyk) czy też wygląd, ubrania, ogólna stylizacja występująca u mówcy (odczytywana jako autoprezentacja) oraz odległość i przestrzeń. Podopieczny, decydując się na pisemny feedback, użyje socjolektu Internetu, który jest wprawdzie językiem pisanym, ale charakteryzuje go lapidarna i bezsprzecznie zwięzła forma (Gawlik-Kobylińska, 2014, s. 8). Zatem podczas prowadzenia zajęć w przestrzeni e-learningowej nauczyciel bardzo często nie jest w stanie zarejestrować emocji, uczuć czy nastawienia swoich podopiecznych, którzy pozostają w ukryciu - za ekranem swojego komputera, z „bezpiecznie” wyłączoną kamerką, a czasem i mikrofonem. Stąd zjawisko uczniowskiej niewidoczności, które zdefiniowałabym jako właściwość zdalnego nauczania, sprowadzającą się do występowania odpowiednich warunków do nieokazywania bądź maskowania swoich emocji, nastroju, nastawienia czy jakiejś aktywności (w tym jej braku) oraz do pojawiania się specyficznych trudności związanych z prowadzeniem transparentnej komunikacji na płaszczyźnie nauczyciel - uczeń.

\section{Niewidoczność jako potrzeba (ukrywania się) katalizowana lękiem}

„Wiecie przecież, jak łatwo stać się niewidzialnym, kiedy się jest bardzo wystraszonym” (Jansson, 1990, s. 152) oznajmia Too-tiki rodzinie Muminków, przyprowadzając do nich Niewidzialne Dziecko. W opowiadaniu autorstwa Tove Jansson główna bohaterka Nini 


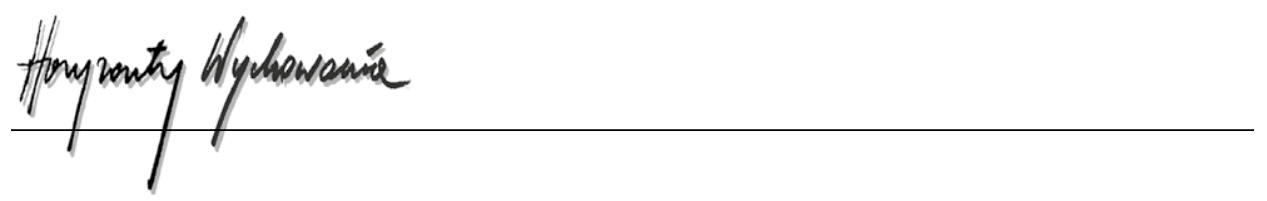

staje się niewidzialna z powodu zachowania ironicznej ciotki, posiadającej zdecydowanie negatywny stosunek do swojej podopiecznej. Opiekunka, stosując wobec dziecka ironię, powoduje, że nieśmiała dziewczynka znika, tracąc swój dotychczasowy wygląd, a więc i swoją tożsamość. Zniknięcie Nini było „symbolicznym aktem” (Gomóła, 2008, s. 149-150), potrzebą wynikającą z jej stanu psychicznego wywołanego trudną relacją z ciotką. Potrzeba ta wydaje się elementem łączącym fikcyjną bohaterkę z dzieckiem, uczniem ukrywającym się za ekranem monitora w czasach pandemii, szczególnie w perspektywie doniesień z badań, w których podkreśla się, że „młodzież często wstydziła się (...) swojego wyglądu podczas trwania zajęć z użyciem kamery internetowej” (Ptaszek i in., 2020). Tendencja do ukrywania się (znikania) wynikać może ze specyficznego strachu przed ośmieszeniem czy brakiem akceptacji, a także z długotrwale odczuwanego lęku przed koniecznością wykorzystywania w podejmowanych działaniach tego, co nieznane i nie do końca opanowane ${ }^{1}$. Z drugiej zaś strony niewidoczność podopiecznych w czasach zdalnej edukacji może mieć swoje źródła w chęci ukrywania się: przed odpowiedzialnością czy dość specyficznymi obowiązkami, które generują inne niż dotychczas formy aktywności.

To, co łączy Nini i ucznia zamkniętego w domu, to specyficzny lęk, który w czasach współczesnych rozprzestrzenia się, multiplikuje i ekspansywnie wrasta w codzienność. To lęk przed tym, nad czym nie można zapanować, przed niewiadomą, przed jutrem i kolejnym tygodniem, w który wgryza się nieustannie drażniąca niepewność. Według Petera Sloterdijka i Macieja Nowickiego przyszło nam żyć „w czasach przerażonych wspólnot" (2008, s. 71), w których lęk określany jest mianem signum temporis (Szpunar, 2018, s. 81). Nasza kultura nazywana jest kulturą strachu - culture of fear (Furedi, 2009), a pewne jej elementy (szczególnie media) przerabiają współczesny świat na coraz efektywniejszą i makabryczniejszą „fabrykę strachu” (Wilkinson, 2008, s. 861). Ponadto w obliczu obecnej sytuacji osoby zaangażowane w distance learning narażone są nieustannie na doświadczenie specyficznego rodzaju lęku - lęku technologicznego. Stale rozwijająca się technologia bowiem z jednej strony fascynuje, zaskakuje, ekscytuje oraz oferuje imponujący wachlarz możliwości, z drugiej zaś przytłacza swoją mglistością, bezwzględną zerojedynkowością oraz nierzadko niezrozumiałością (Szpunar, 2018).

Zawiłości świata technologicznego często przerastają i uczniów, i nauczycieli, generując negatywne emocje, co przekładać się może na samopoczucie psychiczne, które w czasach zdalnego nauczania zarówno uczniowie, rodzice jak i nauczyciele oceniali jako gorsze niż w czasie sprzed pandemii (Ptaszek i in., 2020, s. 28). Odczuwanie lęku przed nieznanym oraz strachu przed wyśmianiem, kompromitacją czy brakiem akceptacji może zainicjować proces krystalizowania się specyficznej potrzeby, jaką jest stopniowe,

\footnotetext{
${ }^{1}$ W literaturze istnieje wyraźne rozróżnienie definicyjne na kategorię strachu i lęku. Dlatego też przyjęłam, że strach to chwilowe uczucie, które można zracjonalizować, a przedmiot tego uczucia jest wyraźny, rozpoznawalny - w odróżnieniu od lęku, którego przyczyną są obiekty rozmyte, dość niejasne. Sam lęk jest uczuciem długotrwałym o stałym podłożu (na podstawie: Szatan, 2012).
} 
acz systematyczne zanikanie za monitorem komputera. Staje się ono w czasach współczesnych potrzebą i słuszne wydaje się jego łączenie z zatracaniem własnej tożsamości w technologicznym gąszczu (nie)możliwości. Stąd też nawiązanie do Niewidzialnego Dziecka, któremu zawieszony został na szyi dzwoneczek, sygnalizujący jego położenie. W czasach zdalnej edukacji ten dzwoneczek to podniesiony kciuk czy dowolna emotikonka wskazująca na obecność, zaangażowanie, zrozumienie lub ich brak. Ikonka kciuka to współczesne hasło-sygnał świadczące o jakiejś (czasem byle jakiej) obecności. Obecności często pozornej.

\section{Niewidoczność jako niebezpieczeństwo - ku deindywiduacji}

Zjawisko uczniowskiej niewidoczności w czasach zdalnego nauczania wiąże się z kilkoma niebezpieczeństwami, wśród których wyraźnie zarysowuje się sposobność wystąpienia deindywiduacji. Definiowana ona jest jako zjawisko utraty „normalnej kontroli nad zachowaniem" (Aronson i in., 1997, s. 366), w związku z czym osoba zdeindywidualizowana działa niestabilnie, poza własną kontrolą (Reicher i in., 1995, s. 168). Do deindywiduacji dochodzi na przykład wtedy, gdy jednostka znajduje się w tłumie i działa razem z osobami zgromadzonymi (w określonym celu), niezależnie od tego, czy działania te są impulsywne, agresywne, prymitywne, nieadekwatne, społecznie nieakceptowane czy też nie. Według Gustave’a Le Bona, Leona Festingera, Siegfrieda Kracauera czy Philipa Zimbardo zachowania w kontekście deindywiduacji są niebezpieczne, prymitywne i destrukcyjne (patologizacja deindywiduacji) (zob: Krajewski, 2019, s. 9), natomiast zdaniem Eda Dienera oraz Stevena Prentice-Dunna i Ronalda W. Rogersa zachowania deindywiduacyjne mogą być zarówno pozytywne, jak i negatywne, w zależności od konkretnej sytuacji i zespołu czynników współistniejących (Reicher i in., 1995, s. 168). Z omawianym zjawiskiem mamy do czynienia w momencie, gdy człowiek zatraca własną tożsamość, osobowość, cechy jednostkowe i zastępuje je tożsamością grupową (Wojciszke, 2002). Jednostka staje się pozornie niewidzialna, chwilowo porzuca to, kim jest, stając się jednocześnie elementem grupowej machiny. Warto podkreślić, że deindywiduacja to nie tylko wtapianie się w grupę i tworzenie „zbiorowej duszy” (Strzelecki i Pawlak, 2012, s. 148), ale także występowanie specyficznych cech i skłonności w momencie „zamaskowania”, czyli zatracenia czy zniekształcenia swojej powierzchowności, zamazania czy też ukrycia swojego wyglądu i cech charakterystycznych. Robert Watson w 1973 roku analizował dane etnograficzne z dwudziestu kultur i stwierdził, że wojownicy zamaskowani lub pomalowani „cechowali się większą skłonnością do zabijania, torturowania i dręczenia jeńców w porównaniu z wojownikami, którzy nie byli zamaskowani w czasie walki" (Aronson i in., 1997, s. 366-367). W związku z powyższym do deindywiduacji dochodzi zatem bardzo często w sytuacjach, które powodują poczucie zmniejszonej odpowiedzialności za własne czyny. Ludzie w tłumie lub w przebraniu zachowują się agresywniej, głośniej, gdyż dostrzegają możliwość łamania zasad czy przekraczania lub przesuwania barier, czując się bezkarni. Ich widoczność jest zaburzona, tak 


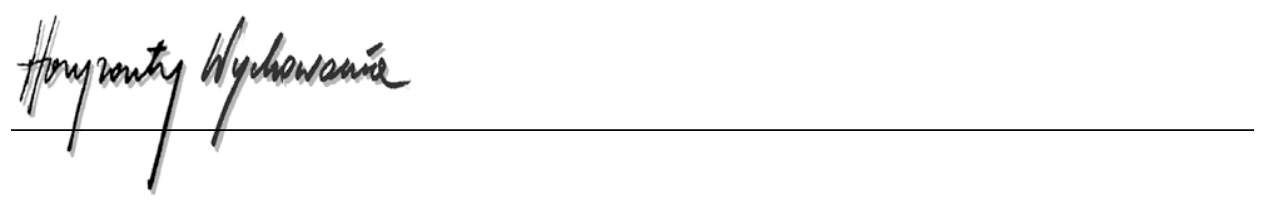

jak widoczność uczniowska podczas zdalnego nauczania. Czytamy, że „deindywiduacja w sieci wiąże się przede wszystkim z poczuciem anonimowości” (Strzelecki i Pawlak, 2012, s. 153), która określana jest jako „immanentna cecha internetu” (Szpunar, 2016, s. 150). Świadomość zaburzonej widoczność (niewidzialny, zamaskowany i niedosięgalny „Ja” po drugiej stronie komputera) powoduje pojawienie się uczucia anonimowości, a to zaś wpływa na odczuwanie zmniejszonej odpowiedzialności za własne czyny i prowadzi do omawianego zjawiska deindywiduacji. W związku z tym stwierdzeniem warto wspomnieć o badaniach Philipa Zimbardo, który wyodrębnił zespół czynników, mogących przyczynić się do pojawienia zjawiska deindywiduacji. Wśród nich jako pierwsze wymienione zostały anonimowość (anonymity) oraz zmienna odpowiedzialność (altered responsibility) (za: Coleman i in., 1999, s. 53), które podczas zdalnego nauczania mogą pojawić się jako następstwo świadomości zaburzonej widoczności. W dużym uproszczeniu - wizualna anonimowość może stwarzać warunki sprzyjające pojawieniu się zjawiska deindywiduacji (Postmes i in., 1998, s. 698).

Oczywiście zjawiskiem deindywiduacji i anonimowości w perspektywie computer-mediated communication (CMC) zajmowano się już wcześniej, a w związku z rozważaniami ukierunkowanymi na anonimowość w sieci szczególnie warto zwrócić uwagę na model SIDE (social identity model of deindividuation effects), czyli na model tożsamości społecznej efektów deindywiduacji, który powstał wskutek wzrostu zainteresowania komunikacją za pośrednictwem komputera i jej społecznymi skutkami. Model SIDE, stanowiący odpowiedź na klasyczną teorię deindywiduacji, przewiduje specyficzne odhamowanie w komunikacji za pośrednictwem komputera, ponieważ tożsamość grupowa staje się bardziej istotna niż tożsamość indywidualna (Coleman i in., 1999, s. 64). Badania dotyczące specyfiki CMC prowadzone są intensywnie, niemniej jednak w niniejszych rozważaniach problem ten został tylko zaakcentowany w związku z omawianym zjawiskiem uczniowskiej niewidoczności. Niewidoczności, która jest bezprecedensowym testem, sprawdzianem kondycji współczesnej edukacji w Polsce.

\section{Niewidoczność jako bezprecedensowy test współczesnej edukacji}

Konsekwentnie pozostając $w$ łączności z inspirującą literaturą, na początku konkluzywnej części niniejszych rozważań pozwolę sobie przytoczyć odpowiedź Profesora Dmuchawca, bohatera książki Brulion Bebe B. autorstwa Małgorzaty Musierowicz, który odpowiada swojej uczennicy pytającej, dlaczego szkoła musi być paskudna:

Szkoła jest zawsze odbiciem tego, co na zewnątrz (...). Bardziej ludzka będzie wtedy dopiero, gdy zmieni się sytuacja zewnętrzna. (...) Ale popatrz: jakoś się trzymamy. Nie tracimy godności. Przynajmniej niektórzy z nas. Czyż nie jest rzeczą chwalebną wyjść na ludzi poprzez trudności i opały? Uczyć się dla siebie samego, po to, żeby być, po prostu, człowiekiem wykształconym. O stopniach nie myśl, mała (Musierowicz, 1991, s. 174). 
Brulion Bebe B. został wydany w 1990 roku, ale przytoczony fragment, choć odnoszący się do wydarzeń z 1988 roku, wydaje się niezwykle aktualny. Szkoła zamknięta w obszarze zdalnego nauczania staje się odbiciem rzeczywistości, w której została zanurzona i która nieustannie na nią oddziałuje, kształtując ją (lub odkształcając). A jest to rzeczywistość przesiąknięta lękiem przed nieznanym oraz strachem przed kolejną oceną, sprawdzianem czy jednoznacznie szufladkującym komentarzem, kolejnymi informacjami i zadaniami. Uczniowie w raporcie Ptaszka i współpracowników przyznawali, że byli źli na nauczycieli w związku z ilością zadawanego materiału, a podczas zajęć często zajmowali się sprawami niezwiązanymi z konkretną lekcją (Ptaszek i in., 2020, s. 29-30). Strach/lęk, technostres, przemęczenie, frustracja czy złość wydają się znaczące wobec zjawiska widoczności w czasach zdalnego nauczania, ponieważ generować mogą potrzebę ukrywania się przed monitorem komputera, stawania się niewidocznym/ nieobecnym, a więc pozornie bezpiecznym, bardziej anonimowym i mniej odpowiedzialnym. Wobec tej sytuacji system edukacji został zdemaskowany. Okazał się systemem nietrwałym, kruchym, bowiem ukierunkowany był i jest na zdobycie odpowiedniej oceny, stopnia, dyplomu, na wejście na wyższy poziom, co wiąże się z dobitnie uwydatnianymi profitami.

Raporty z badań dotyczących zdalnego nauczania wyraźnie podkreślają, że distance learning w Polsce bazował na tradycyjnym modelu nauczania, co „potwierdza wybór metod nauczania i uczenia się. Dominuje praca z podręcznikiem. Prawie 1/3 uczniów stwierdziła, że rola nauczycieli ograniczała się do wskazania wychowankom konkretnych zadań, które muszą zrealizować. W przypadku $24 \%$ ankietowanych zajęcia zdalne ograniczały się do oglądania filmików lub prezentacji multimedialnych odtwarzanych online lub przesyłanych przez nauczyciela. Rzadkością były metody wymagające samodzielności, własnej inwencji i kreatywności” (Plebańska i in., 2020, s. 41). Szkoła, szczególnie w czasach zdalnego nauczania, w sytuacji pojawienia się nieznanego i niepoznanego obszaru technologicznego i konieczności wykorzystywania go w procesie edukacyjno-wychowawczym stała się prostym przekaźnikiem wiedzy/informacji, często opierającym swoją skuteczność na uczniowskim strachu przed niezaliczeniem kolejnego etapu. Paradoksalnie więc bezprecedensowa sytuacja, w której nauczanie zdalne stało się nauczaniem systemowym, przybrała formę sprawdzianu szeroko pojętej edukacji, w której nierzadko brakuje synchroniczności i współodpowiedzialności za podejmowane czynności i w której wciąż bezrefleksyjnie gloryfikuje się konkretny wynik w postaci oceny.

\section{Ku współodpowiedzialności, czyli... wnioski}

Nauczyciel jako osoba podająca i oceniająca, schematyzm, powtarzalność i odtwórczość oraz nieefektywność edukacji zdalnej to cząstkowe wnioski, jakie można skonstruować na podstawie zaprezentowanej w raporcie Plebańskiej i współpracowników analizy odpowiedzi uczniów (2020, s. 38-53). Edukacja (także zdalna) to wyjątkowa przestrzeń spotkań, rozmów, dyskusji, działań, dzielenia się, poznawania i doświadczania. 


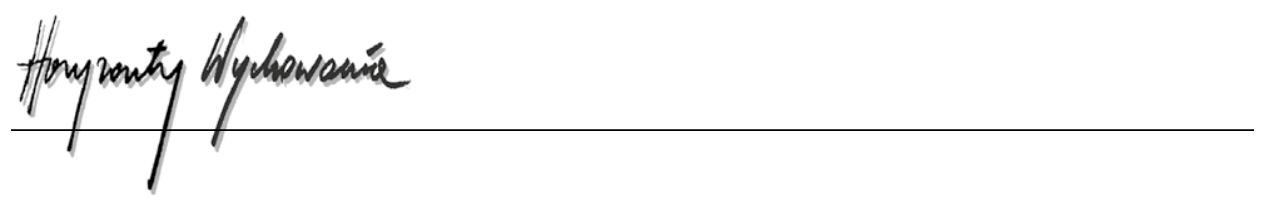

Stworzenie takiego obszaru oddziaływań jest możliwe tylko wtedy, gdy każdy uczestnik i jej współtwórcy będą świadomi współodpowiedzialności, jaką za nią ponoszą. Współodpowiedzialność rozumiana jest w niniejszym artykule jako odpowiedzialność za coś wspólnie z kimś i - scalając poglądy Romana Ingardena (1987, s. 73-96) z przestrzenią oddziaływań edukacyjnych - występuje ona wtedy, gdy:

a) Ktoś ponosi odpowiedzialność, czyli jest za coś odpowiedzialny - razem z kimś, czyli aktywnie ustosunkowuje się (Ingarden, 1987, s. 75) do podejmowanych działań wspólnie z innymi podmiotami zaangażowanymi.

b) Ktoś bierze odpowiedzialność za jakiś czyn i jego wynik - razem z kimś, czyli wspólnie podejmuje działania, przedsięwzięcia i realizuje je z innymi podmiotami zaangażowanymi, z pełną świadomością odpowiedzialności za konkretny efekt/skutek.

c) Ktoś jest za coś pociągany do odpowiedzialności - razem z kimś, czyli wspólnie z innymi podmiotami ponosi konsekwencje podejmowanych działań.

d) Ktoś działa odpowiedzialnie razem z kimś - teraz, by współodpowiedzialnie działać w przyszłości, a więc podejmować decyzje zgodne z własnych charakterem, przekonaniami, opierając się na „ontycznych fundamentach” (Ingarden, 1987, s. 97).

Współodpowiedzialność w edukacji dostrzegalna powinna być zatem w postawach, działaniach, podejmowanych przedsięwzięciach i konkretnych zachowaniach. Może okazać się środkiem zastępczo-zaradczym wobec działań, które podejmowane są w związku z koniecznością otrzymania kolejnej pozytywnej oceny, świadectwa, dyplomu czy zaświadczenia, a więc rozwiązaniem dla edukacji, która często wydaje się opresyjną edukacją strachu. Ten rodzaj edukacji w teście uczniowskiej niewidoczności w czasach zdalnego nauczania wypada co najmniej słabo.

W roku akademickim i szkolnym 2020/2021 większość nauczycieli i ich podopiecznych przeniesiona została do zupełnie nowej rzeczywistości, natarczywie odkształcanej przez medialny kombinat strachu. Ten nowo kreowany świat edukacyjny okazał się obszarem szalenie bipolarym - wąskim, bowiem zamkniętym w granicach monitorowo-klawiaturowych i bazującym na tradycyjnym systemie nauczania oraz przerażająco szerokim/głębokim, gdyż technologicznie oferującym niesamowicie wiele rozwiązań, możliwości i generującym sporo problemów. Nieplanowane zanurzenie uczniów i nauczycieli w technologicznej rzeczywistości jest analogiczne do sytuacji, w której znalazł się bohater filmu Pan od muzyki - Clément Mathieu, który trafia do ośrodka dla trudnej młodzieży o wymownej nazwie Fond de l'Étang, czyli „Dno Stawu”. Na tym dnie podejmuje walkę o „wynurzenie” swoich podopiecznych. Sytuacja polskiej edukacji w perspektywie zdalnego nauczania nie jest łatwa i krystalizuje się w jej obrębie wiele zjawisk, które wymagają analizy, dyskusji, podjęcia odpowiednich działań. Te działania są nieodzowne, niezaprzeczalnie konieczne, by odbić się od filmowego „dna stawu”, które w rzeczywistości może stać się (o ile już nim nie jest) dnem edukacji systemowej. 


\section{BIBLIOGRAFIA}

Aronson, E., Wilson, T.D. i Akert, R.M. (1997). Psychologia społeczna. Serce i umyst (A. Bezwińska-Walerian, tłum.). Wydawnictwo Zysk i S-ka.

Centrum Cyfrowe. (2020). Edukacja zdalna w czasie pandemii. Raport z badań. (2020). https:// centrumcyfrowe.pl/wp-content/uploads/sites/16/2020/05/Edukacja_zdalna_w_czasie_pandemii.pptx-2.pdf

Coleman, L.H., Paternite, C.E. i Sherman, R.C. (1999). A reexamination of deindividuation in synchronous computer-mediated communication. Computers in Human Behavior, 15(1), 51-65. DOI: 10.1016/S0747-5632(98)00032-6

Dobek-Ostrowska, B. (2002). Podstawy komunikacji społecznej. Wydawnictwo Astrum.

Furedi, F. (2009). Culture of fear. Risk-taking and the morality of low expectation. Continuum.

Gawlik-Kobylińska, M. (2014). Komunikacja w nauczaniu zdalnym na przykładzie platformy LMS ILIAS. Journal of Science of the Gen Tadeusz Kosciuszko Military Academy of Land Forces, 4(174), 5-14. DOI: 10.5604/17318157.1143814

Gomóła, A. (2008). Anatomia wstydu, czyli „Opowiadanie o niewidzialnym dziecku”. W: E. Kosowska, G. Kurylenka i A. Gomóła (red.), Wstyd w kulturze: kolokwia polsko-białoruskie (t. 2, s. 147-160). Wydawnictwo Uniwersytetu Śląskiego.

Ingarden, R. (1987). Książeczka o człowieku. Wydawnictwo Literackie.

Jansson, T. (1990). Opowiadania z Doliny Muminków. Nasza Księgarnia.

Krajewski, M. (2019). Wstęp. Deindywiduacja. W: M. Krajewski (red.), Deindywiduacja. Socjologia zachowań zbiorowych (s. 7-20). Fundacja Bęc Zmiana.

Kujawski, J. (2018). Wykluczenie cyfrowe jako forma wykluczenia społecznego. Przypadek Polski. Media i Społeczeństwo, 9, 252-260.

Musierowicz, M. (1991). Brulion Bebe B. Nasza Księgarnia.

Nęcki, Z. (2000). Komunikacja międzyludzka. Antykwa.

Pauluk, D. (2021). Pandemia COVID-19 i (nie)wykorzystany potencjał edukacyjny. Horyzonty Wychowania, 20(53), 39-48. DOI: 10.35765/hw.1963.

Plebańska, M., Szyller A. i Sieńczewska, M. (2020). Edukacja zdalna w czasach COVID-19. Raport z badania. Warszawa: Wydział Pedagogiczny Uniwersytetu Warszawskiego. https://kometa. edu.pl/uploads/publication/941/24a2_A_a_nauczanie_zdalne_oczami_nauczycieli_i_uczniow_ RAPORT.pdf?v2.8

Postmes, T., Spears, R. i Lea, M. (1998). Breaching or building social boundaries? SIDE-effects of computer-mediated communication. Communication Research, 25(6), 689-715. DOI: 10.1 177/009365098025006006

Ptaszek, G., Stunża, G.D., Pyżalski, J., Dębski, M. i Bigaj, M. (2020). Edukacja zdalna: co stało się z uczniami, ich rodzicami i nauczycielami? Gdańskie Wydawnictwo Psychologiczne.

Reicher, S.D., Spears, R. i Postmes, T. (1995). A social identity model of deindividuation phenomena. European Review of Social Psychology, 6(1), 161-198. DOI: 10.1080/14792779443000049

Reimers, F.M. i Schleicher, A. (2020). A framework to guide an education response to the COVID-19 Pandemic of 2020. https://www.hm.ee/sites/default/files/framework_guide_v1_002_harward.pdf

Sloterdijk, P. i Nowicki, M. (2008). Czy Polacy odnajdują szczęście? W: C. Michalski i M. Nowicki (red.), Idee z pierwszej ręki: antologia najważniejszych tekstów „Europy”- sobotniego dodatku do „Dziennika”. Axel Springer Polska.

Strzelecki, W. i Pawlak P. (2012). Deindywiduacja w sieci i środowisku wielkomiejskim. Zeszyty Naukowe Uniwersytetu Szczecińskiego, 29, 147-158. https://wneiz.pl/nauka_wneiz/studia_inf/292012/si-29-147.pdf 


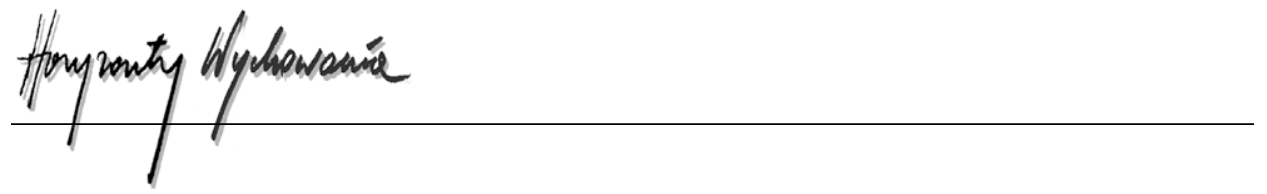

Szatan, M. (2012). Strach a lęk w ujęciu nauk humanistycznych. Studia Gdańskie, 31, 325-342. http://cejsh.icm.edu.pl/cejsh/element/bwmeta1.element.desklight-2ce9efb1-1b1e-44a4-b2dc -2af503ec6ada

Szpunar, M. (2016). Kultura cyfrowego narcyzmu. Wydawnictwo AGH. https://magdalenaszpunar. com/_pliki/Magdalena_Szpunar_kultura_cyfrowego_narcyzmu-srodek.pdf

Szpunar, M. (2018). (Nie)potrzebna wrażliwość. Uniwersytet Jagielloński. https://www.magdalenaszpunar.com/_pliki/Szpunar_Magdalena-(Nie)potrzebna_wrazliwosc.pdf

Wilkinson, I. (2008). W stronę socjologicznej konceptualizacji problemu lęku. W: P. Sztompka i. M. Bogunia-Borowska (red.), Socjologia codzienności (s. 856-883). Wydawnictwo „Znak”.

Wojciszke, B. (2002). Człowiek wśród ludzi. Zarys psychologii społecznej. Wydawnictwo Scholar.

\section{Copyright and License}

This article is published under the terms of the Creative Commons Attribution - NoDerivs (CC BY- ND 4.0) License http://creativecommons.org/licenses/by-nd/4.0/ 